DOI 10.37882/2223-2974.2021.03.02

\title{
СОДЕЙСТВИЕ ОРГАНА ДОЗНАНИЯ ПРОЦЕССУАЛЬНОЙ ДЕЯТЕЛЬНОСТИ СЛЕДОВАТЕЛЯ ПРИ ПРОИЗВОДСТВЕ ОТДЕЛЬНЫХ СЛЕДСТВЕННЫХ ДЕЙСТВИЙ (ПРОИЗВОДСТВО ОБЫСКА В СОВРЕМЕННОЙ РОССИИ)
}

\section{ASSISTANCE OF THE INVESTIGATIVE AUTHORITY IN THE PROCEDURAL ACTIVITIES (PRODUCTION OF SEARCH IN MODERN RUSSIA)}

\section{Aristarkhov}

Summary: The article outlines the actual problems of interaction between the investigator and the investigative authority in the investigation of crimes. Recent examples from the author's practice are given, on the basis of which conclusions are drawn on the problems of this article. The assistance of the investigative authority of the procedural activity of the investigator in the production of certain investigative actions is one of the most active types of interaction between the investigator and the investigative authority. The criminal procedural forms of interaction in a criminal case, in particular, include the assistance of the investigative authority of the procedural activity of the investigator in the performance of certain investigative actions. According to the author, such an investigative action as conducting a search includes both of the aforementioned forms of interaction between the investigator and the inquiry authorities, and is also the clearest example of such interaction. The search is one of the most effective investigative actions, as well as an example of the interaction of the investigator with the investigative authority. Unfortunately, in modern Russia, the practice of searches, examinations and other penetrations of government officials into residential premises and offices under various pretexts, as well as the statistics of court decisions on violation of the inviolability of the home, indicate that there are currently no effective legal methods of protection against such interference.

Keywords: interaction, investigator, operational-search activity, search, investigative actions.

\author{
Аристархов Дмитрий Анатольевич \\ Аспирант, ФГБОУ ВО «Башкирский государственный \\ университет», г. Уфа \\ Dimaris90@mail.ru
}

Аннотация: В статье обозначаются актуальные проблемы взаимодействия следователя с органами дознания, при расследовании преступлений в современных условиях. Приводятся недавние примеры из практики автора, на основе которых и делаются выводы по проблематике настоящей статьи. Содействие органа дознания процессуальной деятельности следователя при производстве отдельных следственных действий является одним из наиболее активных видов взаимодействия следователя с органом дознания. К уголовно-процессуальным формам взаимодействия по уголовному делу, в частности, относится содействие органа дознания процессуальной деятельности следователя при производстве отдельных следственных действий. По мнению автора, такое следственное действие, как производство обыска, включает в себя обе вышеупомянутые формы взаимодействия следователя с органами дознания, а также является ярчайшим примером такого взаимодействия. Обыск является одним из эффективнейших следственных действий, а также примером взаимодействия следователя с органами дознания. К сожалению, в современной России практика обысков, осмотров и прочих проникновений представителей власти в жилые помещения и офисы под разными предлогами, а также статистика судебных решений на нарушение неприкосновенности жилища свидетельствует 0 том, что эффективных правовых способов защиты от такого рода вмешательства на сегодняшний день не существует.

Ключевые слова: взаимодействие, следователь, оперативно-розыскная деятельность, обыск, следственные действия.
$\Phi$ ормы взаимодействия следователя и органа дознания различаются в правовой литературе в зависимости от их содержания и нормативного закрепления способов его осуществления. С учетом этих критериев различают две основные формы взаимодействия: процессуальную и организационную. $\mathrm{K}$ уголовно-процессуальным формам взаимодействия по уголовному делу в частности относится содействие органа дознания процессуальной деятельности следователя при производстве отдельных следственных действий (например, при осмотре места происшествия, производстве обыска, проверки и уточнении показаний на месте, задержании членов организованной преступной группы и т.д.)[1] Следует отметить, что, по мнению автора, такое следственное действие, как производство обыска, включает в себя обе вышеупомянутые формы взаимодействия следователя с органами дознания, а также является ярчайшим примером такого взаимодействия. Так, сложно отрицать тот факт, что при производстве обыска, помимо взаимодействия, определяемого уголовно-про- 
цессуальным законодательством Российской Федерации, необходимо и организационное взаимодействия следователя с органами дознания. Только лишь в этом случае такое следственное действие принесет максимальный результат. Кроме того, за последние десять с половиной лет российские правоохранительные органы получили 1976021 разрешение судов на производство обыска или осмотра в жилище, что составляет $96,32 \%$ от общего числа запросов.[2] Таким образом, обыску подверглось каждое 27 жилище в стране.[3] При этом общее число запросов растет, увеличившись за этот же период примерно на половину. Таким образом, на сегодняшний день в России ежедневно, в среднем, проходит более пятисот обысков.

Также, в 97,85\% случаев суды разрешали обследование жилища в качестве оперативно-розыскного мероприятия (до возбуждения уголовного дела).

Вышеприведенные данные свидетельствуют о том, что содействие органа дознания процессуальной деятельности следователя при производстве отдельных следственных действий является одним из наиболее активных видов взаимодействия следователя с органом дознания. Добавим, что обыск - это следственное действие, направленное на принудительное обследование участников местности, помещений, тела человека, его одежды и личных вещей, осуществляемое в рамках уголовно- процессуального закона управомоченным на то лицом при соблюдении гарантий прав и законных интересов граждан и юридических лиц с целью поиска (обнаружения) и изъятия (задержания) конкретных источников доказательственной информации (материальных объектов), могущих иметь значение для дела. Обыск в ходе расследования может производиться и тогда, когда объектом поиска являются разыскиваемое лицо, труп или его части. То есть, обыск проводится в случаях, когда имеются достаточные основания полагать, что в определенном помещении, или ином месте, или у какого- либо лица находятся орудия преступления, предметы и ценности, добытые преступным путем, либо другие предметы и документы, могущие иметь значение для дела. Следует также отметить, что в ряде случаев обыск является практически обязательным элементом расследования, применяемым по умолчанию - дела о наркотиках, о преступлениях в сфере экономики, о коррупционных преступлениях, а также об экстремизме. В соответствии с УПК РФ обыск проводится на основании решения суда (в жилище) либо постановления следователя (во всех остальных случаях). Однако, в исключительных случаях, не терпящих отлагательства, обыск в жилище может быть произведен без получения судебного разрешения, но с последующим (в течение 3 суток) уведомлением суда и прокурора. В 2017 году Верховный суд РФ разъяснил, что к таким исключительным случаям относятся, в частности, ситуации, когда промедление может позволить подозреваемому скрыться либо существует угроза уничтожения или сокрытия предметов, или орудий преступления. [4] Согласно статье 25 Конституции РФ, жилище неприкосновенно, никто не вправе проникать в жилище против воли проживающих в нем лиц иначе как в случаях, установленных федеральным законом, или на основании судебного решения. Процедура обыска, описанная в УПК РФ, является одним из исключений, предусмотренных Конституцией. Однако определения «жилища», а также пределы распространяющейся на нее неприкосновенности могут трактоваться по-разному. Следует также отметить, что УПК РФ дает определение этого понятия как жилого помещения, используемого для постоянного или временного проживания (статья 5). Такая узкая трактовка обусловила устойчивую практику, когда за судебным разрешением следствие обращается лишь в тех случаях, когда необходимо провести обыск в квартире или официально зарегистрированном жилом доме. Более широкий подход демонстрирует Европейский суд по правам человека, рассматривающий неприкосновенность жилища как лишь один из аспектов права на уважение частной и семейной жизни. Суд при этом рассматривает обыск как одну из несомненных форм вмешательства в право на уважение частной жизни.

Европейский суд считает, что установление того, является ли конкретное место «жилищем», на которое распространяются гарантии статьи 8 Конвенции о защите прав человека и основных свобод, должно определяться в каждом случае отдельно с учетом конкретных обстоятельств, прежде всего, наличия достаточных продолжающихся связей с конкретным местом проживания. Таким образом, статус «жилища» может быть распространен на случаи проживания (1) в доме, принадлежащем другому лицу (отель, аренда); (2) в помещениях без законного основания (в квартире, на проживание в которой у лица не было права); (3) в мобильных местах, автоприцепах и т.п.; (3) в летних домиках и коттеджах, а также (4) в помещениях делового предприятия при отсутствии четкого различия между собственным офисом и частным местом проживания, или между частной и предпринимательской деятельностью. Последний критерий очень важен, поскольку позволяет распространить защиту, к примеру, на адвокатские конторы и помещения неправительственных организаций. С апреля 2017 года адвокатские офисы в России пользуются большей формальной защитой, нежели жилища граждан - в отношении последних, как уже указывалось, можно провести обыск без разрешения суда, получив одобрение уже после проведения следственного действия. С адвокатами такая схема больше не действует. Существовавшее ранее противоречие между статьей 8 Федерального закона «Об адвокатской деятельности и адвокатуре в Российской Федерации», устанавливающей что производство любых оператив- 
но-розыскных мероприятий и следственных действий в отношении адвокатов возможно только на основании судебных решений, и статьи 182 УПК РФ, требующей обращаться в суд только в связи с проведением обыска в жилище, позволяло силовикам проводить обыски в адвокатских помещениях в общем порядке без решения суда. Конституционный суд в 2015 году, сославшись на правовую позицию Европейского суда по правам человека, постановил, что обыск, связанный с доступом к материалам адвокатского производства, возможен только по решению суда. [5] В то же время без закрепления в уголовно-процессуальном законодательстве эта формулировка мало что добавляла к существующему порядку вещей. С апреля 2017 года в УПК РФ включена статья 450.1, устанавливающая, что обыск, а также осмотр и выемка в отношении адвоката возможны только после возбуждения в отношении него уголовного дела, на основании судебного решения и в присутствии члена адвокатской палаты.

Показательно дело об обысках у московского адвоката Максима Загорского, проведенных ФСБ уже после вступления названных поправок в силу. Попытавшись применить опробованную схему с проведением обыска в условиях, не терпящих отлагательства, следователи уже после проведения обысков обратились в Пресненский суд Москвы, который признал их действия законными. Однако Московский городской суд удовлетворил жалобы защиты адвоката, подтвердив единственный возможный порядок проведения обыска у адвоката - только после получения судебного разрешения и в присутствии члена адвокатской палаты[6]. Следует отметить, что обыски как способ сбора доказательств существовали во все времена. С начала $90-x$ годов в России возник термин «маски-шоу», описывающий обыск с силовой поддержкой вооруженного спецназа в масках, как инструмент недобросовестной конкуренции и эффективное средство оказания давления на партнеров или соперников по бизнесу. Одним из первых случаев адаптации такой практики к политическим делам стало уголовное дело в отношении руководства холдинга «Медиа-Мост», в результате которого телеканал НТВ перешел под контроль государства. В период с мая 2000 по март 2001 года в помещениях «Медиа-Моста», офисах НТВ и квартирах руководства холдинга прошла серия обысков с участием сотрудников Генпрокуратуры, ФСБ и налоговой полиции. [7] В отличие от бизнес-сектора, где одной из важнейших целей проникновения является эмоциональное подавление конкурента, в политических делах чаще всего достигается более широкая задача - запугивание активистов, затруднение работы организации. Например, по итогам обысков в Межрегиональной общественной организации «Открытая Россия» в 2006 году не были предъявлены объявление, что свидетельствует именно о том, что настоящей целью была именно нейтрализация и прекращение общественной деятельности организации. [8] Также, в мае 2012 года в рамках «Болотного дела» проходили обыски у лидеров, однако обвинения по делу «6 мая» предъявлены так же не были. По данным, анонсированным Международной правозащитной организацией «Агора», было рассмотрено 600 обысков у гражданских активистов и представителей преследуемых организаций за последние несколько лет. [9] Таким образом были обнаружены следующие используемые элементов запугивания - раннее время (в более чем 60 случаях обыск начинался в промежутке между 6 и 8 часами утра); применение спецсредств, насилия, угроз, демонстрация оружия; обыски у близких родственников (около 50 случаев); взлом дверей или вход через окна (70 случаев). Как яркий пример в этой связи можно рассмотреть обыски в домах крымских татар - они часто проводятся массово, ранним утром с участием сотрудников ФСБ и спецназа, сопровождаются вскрытием дверей, недопуском адвокатов, запретом пользоваться телефонами. Так, по сообщению «Крым. Реалии», 11 февраля 2016 года сотрудники ФСБ провели одновременные обыски сразу в 8 домах крымских татар[10]. «ОВД-Инфо» приводит слова координатора Крымской контактной группы по правам человека Абдурешита Джеппарова: «Обыски проводили люди в масках, которые штурмовали дома, выламывали двери и окна, пострадали дети». Сообщалось также, что к обыскиваемым не допускают адвокатов и запрещают говорить по телефону на крымско-татарском языке[11]. Помимо крымских татар объектами массовых регулярных обысков становятся представители преследуемых оппозиционных общественных организаций. Проникновения в квартиры и офисы активистов могут преследовать различные цели, одна из которых - изъятие явно некриминальных предметов и информационных материалов с целью затруднения деятельности организации. Как правило, изъятия в этом случае органами правопорядка объясняются ведением той или иной организацией экстремистской деятельности. В большинстве случаев, спустя несколько недель изъятые материалы были возвращены, экстремизма в них обнаружено не было. [12]

Известны и следующие случаи. Со слов адвоката Ильнура Шарапова, во время обыска у одного из обвиняемых по уголовному делу следователь ФСБ изъял flashноситель, на котором в ходе осмотра была обнаружена аудиозапись разговора обвиняемого о планах диверсии. По факту никакого очевидного смысла в хранении дома существенного доказательства по делу не было и наиболее вероятная версия случившегося - попытка следователя таким образом легализовать данные скрытой аудиозаписи, которую осуществил внедренный в группу агент. Важно заметить, что в последние годы обыски стали одними из важных компонентов мероприятий, которые власти стали вести не только в отношении своих по- 
литических оппонентов, о чем свидетельствует широкое освещение в эфире федеральных телеканалов обысков у представителей власти - губернаторов Хорошавина и Гайзера, руководителя Федеральной таможенной службы Бельянинова, членов правительства Дагестана. Итак, обыск является одним из эффективнейших следственных действий, а также примером взаимодействия следователя с органами дознания. К сожалению, на сегодняшний день практика обысков, осмотров и других проникновений представителей власти в жилые помещения и офисы под разными предлогами, а также статистика судебных решений на нарушение неприкосновенности жилища свидетельствует о том, что эффективных правовых способов защиты от такого рода вмешательства в современной России не существует. Судебный контроль в этой сфере является довольно формальным, возможность обжаловать обыск, существующая на бумаге, малоэффективна на практике. В 2010 году Конституционный суд Российской Федерации по жалобе юриста Дениса Федорова указал, что у лица, в отношении которого был проведен незаконный обыск имеется право требовать возмещения морального вреда, причиненного незаконными действиями органов власти и должностных лиц, которое реализуется в общем порядке. Такой вывод сделал Конституционный суд несмотря на то, что УПК не считает обыск мерой принуждения и, соответственно, не распространяет на него правила реабилитации. Кроме того, учитывая незначительный размер компенсаций, это не решает проблемы защиты.

\section{ЛИТЕРАТУРА}

1. Гельдибаев, Мовлад Хасиевич Уголовный процесс: учебник для студентов вузов, обучающихся по юридическим специальностям / М.Х. Гельдибаев, В.В. Вандышев. — 3-е изд., перераб. и доп. - М.: ЮНИТИ-ДАНА, Закон и право. - 719 с. 2012

2. По данным Судебного департамента при Верховном Суде Российской Федерации // http://www.cdep.ru

3. По данным Всероссийской переписи населения 2010 в России насчитывается 54,6 млн. частных домохозяйств // http://www.gks.ru/free_doc/new_site/ perepis2010/croc/perepis_itogi1612.htm

4. Постановление Пленума Верховного Суда РФ от 01.06.2017 N 19 «0 практике рассмотрения судами ходатайств о производстве следственных действий, связанных с ограничением конституционных прав граждан (статья 165 УПК РФ)»

5. Постановление Конституционного Суда РФ от 17.12.2015 N 33-П «По делу о проверке конституционности пункта 7 части второй статьи 29, части четвертой статьи 165 и части первой статьи 182 Уголовно-процессуального кодекса Российской Федерации в связи с жалобой граждан А.В. Баляна, М.С. Дзюбы и других»

6. Статья о заседании в Московском городском суде // http://fparf.ru/news/all_news/news/42753/

7. Статья о переходе прав на телеканал НТВ // http://origin.agentura.ru/timeline/2000/oligarh/?print=Y

8. По данным Википедии // https://ru.wikipedia.org/wiki/0ткрытая_Россия

9. Международный доклад издательства Агора // https://www.agora.legal/news/2018.03.29/Doklad-Mezhdunarodnoi-Agory-V-Rossii-ne-sushestvuetneprikosnovennosti/694

10. В Крыму ФСБ проводит одновременно 8 обысков в домах крымских татар - адвокат. Крым. Реалии. 11.02.2016 // https://ru.krymr.com/a/news/27545031.html

11. При обысках в домах крымских татар задержали не менее восьми человек. ОВД-Инфо. 11.02.2016 // https://ovdinfo.org/express-news/2016/02/11/pri-obyskah-v-domah-krymskih-tatar-zaderzhali-ne-menee-vosmichelovek

12. Криминалисты Орла не нашли экстремизма в листовках Навального. Радио Свобода. 09.08.2017 // https://www.svoboda.org/a/28667473.html 